\title{
Double inferior vena cava in gynaecological oncology surgery
}

\author{
Marina Sousa Gomes 지, ${ }^{1}$ Catarina Pardal, ${ }^{2}$ Carla Monteiro, ${ }^{2}$ Paula Serrano ${ }^{2}$
}

${ }^{1}$ Department of Obstetrics and Gynecology, Unidade Local de Saúde do Alto Minho EPE, Viana do Castelo, Portugal

${ }^{2}$ Department of Obstetrics and Gynecology, Hospital de Braga, Braga, Portugal

\section{Correspondence to} Dr Marina Sousa Gomes; marinarsgomes@gmail.com

Accepted 5 December 2020

Check for updates

(C) BMJ Publishing Group Limited 2020. No commercial re-use. See rights and permissions. Published by BMJ.

To cite: Sousa Gomes M, Pardal C, Monteiro C, et al. BMJ Case Rep

2020:13:e240361.

doi:10.1136/bcr-2020-

240361

\section{DESCRIPTION}

A 45-year-old premenopausal woman, nuligest, with no relevant medical history, was admitted to umbilical hernia repair surgery. During the procedure, a suspicious nodule in the peritoneum sac was found to bulge outwards the hernia hole and was removed, and a diagnostic laparoscopy was performed confirming peritoneal carcinomatosis. The anatomopathological examination demonstrated high-grade serous carcinoma, probably from ovarian/tubal origin. CT imaging revealed ascites, a mass with $8 \mathrm{~cm}$ in diameter in the left adnexal region and a mass with $4 \mathrm{~cm}$ in the right adnexal region. The serum CA-125 levels were $454 \mathrm{ng} / \mathrm{mL}$ (normal, $<35 \mathrm{U} / \mathrm{mL}$ ). The multidisciplinary team decided on neoadjuvant chemotherapy with paclitaxel and carboplatin. After four cycles, an interval debulking surgery was performed, including total hysterectomy, bilateral oophorectomy, omentectomy and retroperitoneal lymphadenectomy (pelvic and lomboaortic). During the surgery, an unreported double inferior vena cava (IVC) with interiliac communication ( $\mathrm{IiC}$ ) from the left to the right common iliac vein was diagnosed (figure 1). Preoperative CT failed to diagnose this anomaly. The right common iliac vein and an $\mathrm{IiC}$ joined to form the right IVC. The right IVC ascended along the right side of the abdominal aorta. The left IVC arose by the union of the left common iliac vein and IiC. The IiC between the duplicated IVC ran obliquely upwards from left to right. The left IVC coursed cranially along the left side of the abdominal aorta and terminated on the left renal vein. The left ovary vein drained into the left renal vein after the union with left IVC. The origin, the course and the territories of the other vessels appeared normal. The kidneys and the ureters were also normal. Lymphadenectomy was performed without any complications.

Findings from the pathological evaluation indicated that the tumour was limited to the ovaries, with 46 negative nodes. As adjuvant therapy, the patient received paclitaxel and carboplatin. Olaparib as maintenance therapy was proposed because of somatic BRCA mutation positive status. At a follow-up of 8 months, the patient remains disease free.

Retroperitoneal lymph node dissection remains an integral part of the treatment of patients with gynaecological carcinomas, for staging early ovarian cancer patients, for primary surgical cytoreduction in advanced-stage disease and for secondary surgical cytoreduction. ${ }^{12}$ This procedure is associated with higher complication rates. Awareness of anatomic

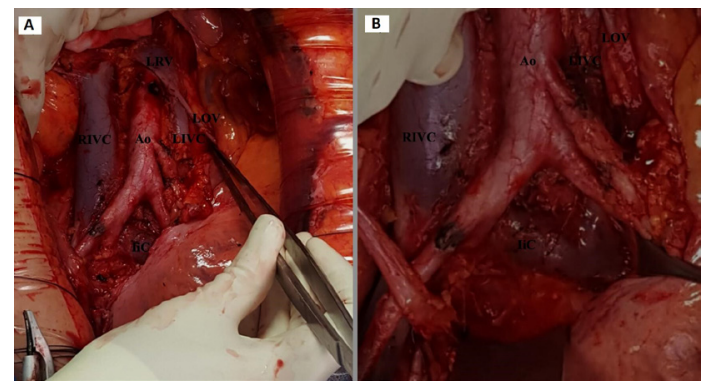

Figure 1 Photographs showing duplicated inferior vena cava (IVC). (A) On both sides of the abdominal aorta a venous vessel, double IVC, is identified. (B) The interiliac communication between the duplicated IVC ran obliquely upwards from left to right. $\mathrm{AO}$, abdominal aorta; IIC, interiliac communication; LIVC, left inferior vena cava; LOV, left ovary vein; LRV, left renal vein; RIVC, right inferior vena cava.

\section{Learning points}

Pelvic surgeons need to have detailed knowledge about the retroperitoneal vascular anatomy.

- Double inferior vena cava is present in $1 \%-3 \%$ of the general population. When this anomaly had not been identified, fatal and uncontrollable bleeding can occur.

- Previous recognition of anatomic variations provides better surgical planning.

variations is crucial to reduce surgical risk. Laparotomy or minimally invasive approach (laparoscopic or robotic) are secure options depending on surgeon expertise. ${ }^{13}$

Double IVC is present in $1 \%-3 \%$ of the general population and arises from the persistence of both supracardinal veins in the subrenal tract. ${ }^{45}$ According to Morita et al, these anomalies are classified according to the pattern of $\mathrm{IiC}$, with the present clinical case representing a type $2 \mathrm{~b}$ (double IVC with IiC from the left common iliac vein), which occurs in approximately $40 \%$ of cases.$^{67}$ This anomaly can create clinical problems in gynaecological oncology surgery and serious haemorrhage, mainly from IiC. When IVC anomalies had not been identified preoperatively, fatal and uncontrollable bleeding has been reported in $10 \%$ of patients. ${ }^{8}$

Contributors MSG: contributed to the conception, design and drafting of the article, and participated in patient's care. CP: contributed to conception, design and drafting of the article, participated in patient's care and supervised all the decisions 
concerning the patient. CM: contributed to the patient's care, supervised all the decisions concerning the patient and the writing process. PS: contributed to the patient's care, supervised all the decisions concerning the patient and the writing process.

Funding The authors have not declared a specific grant for this research from any funding agency in the public, commercial or not-for-profit sectors.

Competing interests None declared.

Patient consent for publication Obtained.

Provenance and peer review Not commissioned; externally peer reviewed.

\section{ORCID iD}

Marina Sousa Gomes http://orcid.org/0000-0002-7858-8225

\section{REFERENCES}

1 Gallotta V, Federico A, Gaballa K, et al. The role of robotic aortic lymphadenectomy in gynecological cancer: surgical and oncological outcome in a single institution experience. J Surg Oncol 2019;119:355-60.
2 Gallotta V, Giudice MT, Conte C, et al. Minimally invasive salvage lymphadenectomy in gynecological cancer patients: a single institution series. Eur J Surg Oncol 2018;44:1568-72.

3 Gueli Alletti S, Petrillo M, Vizzielli G, et al. Minimally invasive versus standard laparotomic interval debulking surgery in ovarian neoplasm: a single-institution retrospective case-control study. Gynecol Oncol 2016:143:516-20.

4 Hirsch DM, Chan KF. Bilateral inferior vena cava. JAMA 1963;185:729.

5 Zhang L, Yang G, Shen W, et al. Spectrum of the inferior vena cava: MDCT findings. Abdom Imaging 2007;32:495-503.

6 Morita S, Higuchi M, Saito N, et al. Pelvic venous variations in patients with congenital inferior vena cava anomalies: classification with computed tomography. Acta Radiol 2007:48:974-9.

7 Chen H, Emura S, Nagasaki S, et al. Double inferior vena cava with interiliac vein: a case report and literature review. Okajimas Folia Anat Jpn 2012;88:147-51.

8 Aljabri B, MacDonald PS, Satin R, et al. Incidence of major venous and renal anomalies relevant to aortoiliac surgery as demonstrated by computed tomography. Ann Vasc Surg 2001;15:615-8.

Copyright 2020 BMJ Publishing Group. All rights reserved. For permission to reuse any of this content visit

https://www.bmj.com/company/products-services/rights-and-licensing/permissions/

BMJ Case Report Fellows may re-use this article for personal use and teaching without any further permission.

Become a Fellow of BMJ Case Reports today and you can:

- Submit as many cases as you like

- Enjoy fast sympathetic peer review and rapid publication of accepted articles

- Access all the published articles

- Re-use any of the published material for personal use and teaching without further permission

\section{Customer Service}

If you have any further queries about your subscription, please contact our customer services team on +44 (0) 2071111105 or via email at support@bmj.com.

Visit casereports.bmj.com for more articles like this and to become a Fellow 